\title{
Jurisdiction Over Foreign Corporations: Actions Arising Out of Acts Done Within the Forum
}

\author{
J.P.McBaine*
}

International Shoe Co. v. State of Washington is an interesting and important decision of the Supreine Court of the United States in the field of procedure. ${ }^{1}$ One of two main questions before the Court was the much discussed and litigated question of jurisdiction to render a personal judgment against a foreign corporation which has not been granted a license to do business in a state where suit has been instituted. ${ }^{2}$

The foreign corporation in the instant case was a Delaware corporation which had its principal place of business in St. Louis, Missouri. It was engaged in the business of manufacturing and selling shoes. Its product was distributed in interstate commerce from several branches outside the State of Washington. It had no place of business in Washington and made no contracts there. During a period of years-from 1937 to 1940 -it enployed eleven to thirteen salesmen whose activities were directed by company officials in St. Louis. The salesmen worked upon a commission basis. In each year they had been paid commissions by the Shoe Company of more than $\$ 31,000$. They were supplied with samples which they displayed to retail dealers. Sometimes they rented sample rooms for which they paid and were reimbursed by the corporation. Their authority was limited to exhibition of samples and solicitation of orders at specified prices. When orders were received they were transmitted to St. Louis for acceptance or rejection. When accepted the merchandise was shipped f.o.b. from points outside the state of Washington. The salesmen, who lived in Washington, had no authority to contract or make collections.

*Alexander F. and May T. Morrison, Professor of Law, University of California.

1 (Dec. 3, 1945) U.S. 66 S. Ct. 154, 90 L. Ed. 109.

2 The other question, a tax question, was whether a foreign corporation is subject to $a$ liability to contribute to a state unemployment compensation fund, based upon cornmissions paid its salesmen who solicit business there. The Court said that the riglit to employ labor is an appropriate subject of taxation. This question is not discussed in this essay. 
The supreme court of Washington held (1) that the proper courts of that state had jurisdiction over the corporation in an action instituted by the state to collect taxes alleged to be due it, ${ }^{3}$ and (2) that the corporation owed taxes because of these employees for a state unemployment fund. Upon an appeal to the Supreme Court of the United States, the decision was affirmed. The conclusion was that the state of Washington had not violated the due process clause of the Constitution of the United States. The Shoe Company relied upon several well-known decisions of the Supreme Court of the United States, wherein the facts were similar, in which it had been held that no jurisdiction was obtained over the foreign corporation. These, and other decisions of the United States Supreme Court have applied the "presence" theory to decide the jurisdictional question. Briefly stated that theory is that a corporation is a legal person, concededly a fiction, and like a natural person is subject to the jurisdiction of a court of a foreign state when present there and duly served there with process. A corporation has been said by the Supreme Court of the United States to be present in the foreign state "only if it is doing business within the state in such manner and to such extent as to warrant the inference that it is present there." ${ }^{6}$ The

3 International Shoe Co.v. State (Jan. 4, 1945) 122 Wash. Dec. 135, 154 P. (2d) 801. The Washington court discussed at length the many decisions, state and federal, dealing with the question whether soliciting business is sufficient to sustain jurisdiction. It apparently was of the opinion that it is sufficient where there is continuous solicitation, such as in the instant case, but it pointed out that the Shoe Company also did other acts in the state which hrought the "case well within the solicitation plus rule." There was a dissent by Chief Justice Simpson, in which Millard, J. concurred. They were of the opinion that systematic solicitation of business by agents of a foreign corporation is not sufficient to give jurisdiction. They relied heavily upon Green v. Chicago, Burlington \& Quincy Ry. Co. (1907) 205 U. S. 530, and distinguish International Harvester Co. v. Kentucky (1914) 234 U.S. 579 on the ground that the agents of the foreign corporation in that case had authority to make collections which they characterized as "local business". They disapproved of the idea, which they conceded has some judicial support, that systematic solicitation produces a "flow of business" in the state which affords a basis for jurisdiction.

4 Green v. Chicago, Burlington \& Quincy Ry. Co., supra note 3, at 533 ; International Harvester Co. v. Kentucky, supra note 3, at 587; Philadelphia \& Reading Ry. Co. v. McKibbin (1917) 243 U.S. 264, 268; People's Tobacco Co. v. American Tobacco Co. (1918) 246 U.S. 79, Ann. Cas. 1918C, 537.

5 Philadelphia \& Reading Ry. Co. v. McKihben, suppa note 4.

${ }^{6}$ Brandeis, J. in Philadelphia \& Reading Ry. Co. v. McKibben, supra note 4. In that case it was held that a railroad company having no tracks, docks, or other property, or freight or passenger ticket offices, or agents, in New York was not present there and hence was not subject to the jurisdiction of the United States district courts of New York. The railroad, a Pennsylvania corporation, sent into New York over connecting 
opinion in the instant case rejects the "presence" theory. The "presence" theory, says Chief Justice Stone, writing the main opinion, begs the question. He states that the term "presence" merely symbolizes the activities of corporate agents which courts deem sufficient to satisfy the demands of due process. Rejection of the "presence" theory obviously compelled announcement of a suitable alternative and, as was to be expected, another theory was announced as furnishing a better solution of this perplexing problem. ${ }^{7}$ The new theory

carriers, its loaded freight cars which were in due course of business returned. A portion of the freight charged to the shipper was paid to the foreign corporation. The connecting carrier also issued coupon tickets over its lines and the lines of the foreign corporation and accounted to the latter for its proper share of the fares paid. The connecting carrier also caused to be displayed signs bearing the name of the foreign corporation and listed its name in the New York telephone directory. These things were designed to facilitate and encourage business. The action was for personal injury received by plaintiff, an employee, while working in New Jersey.

7 Justice Black wrote a separate opinion concurring in the result, which leaves something to be desired. He first stated that the appeal should be dismissed because it was frivolous, that there was no merit in either jurisdictional contention. He was of the opinion that the state unquestionably had the power to levy the tax and to enforce the levy in its courts by an appropriate action and he said that it is "unthinkable" that the due process clause was ever intended to prohibit a state from doing so. He said that the inajority had "engaged in an unnecessary discussion"; had announced "vague Constitutional criteria"; and had introduced "uncertain elements" which had a tendency to curtail the exercise of state powers. He stated that the rule announced means that jurisdiction exists if the Supreme Court of the United States concludes that it is "reasonable" to subject corporations to suit in foreign states. He states that although the terms "fair play" and "substantial justice" have previously been used by the Court that it did not mean that legislative enactinents should be held lacking in due process if the Court deemed they are "contrary to natural justice". He states that it is "judicial deprivation" to condition state powers upon the "notion" of the Supreme Court of the United States as to whether "fair play" was had or upon the ground that it is more "convenient" for the corporation to be sued elsewhere. He asserts that there should not be superimposed upon the Constitution of the United States the "natural justice" concept which could lead to drastic abridgment of such democratic safeguards as freedoun of speech, the press and religion and the right to counsel; that use of the natural justice concept "makes judges the supreme arbiters of the country's laws and practices." He observes that, while here the state's power was upheld, tomorrow a state or federal statute may be stricken down because "it does not conform to this court's idea of natural justice."

Since he was of the opinion that the najority engaged in "an unnecessary discussion" of the due process clause he may well have concluded that it was appropriate for him to refrain from stating affirmatively his opinion as to what is a proper test to apply to determine when a state has jurisdiction over foreign corporations in actions arising out of acts done there. His concurrence, however, was based upon some rule of law. Perhaps his agreement in the result and his observations should be interpreted as ineaning that jurisdiction exists over an action arising out of acts done by a foreign corporation in the forum. In view of the importance of the question, and that there is no obvious difference between actions to recover taxes and many other civil actions, it is hard to 
seemingly is that the demands of due process are met by the activities of the agent or agents in the forum if it is "reasonable in the context of our federal system of government, to require the corporation to defend the particular suit which is brought therein." Relevant in this connection, it is said, is "an estimate of the inconveniences which would result to the defendant from a trial of the action in a foreign jurisdiction."s

Discussing the "presence" theory the learned Chief Justice states, citing cases to support the statement, that when the activities of the foreign corporation have been continuous and systematic, the courts of the state have jurisdiction over the corporation as to actions arising out of acts done there. ${ }^{9}$ He refers also to previous decisions of the Supreme Court of the United States holding that where there is only a single act or only isolated acts of an agent or agents of a foreign corporation the state where such acts occur has no jurisdiction over actions not arising out of such single or isolated acts. ${ }^{10} \mathrm{He}$ next mentions a third class of cases, viz., where there have been continuous operations of a substantial kind of a foreign corporation in another state and the holdings are that there is jurisdiction of actions arising out of acts done elsewhere. ${ }^{11} \mathrm{He}$ then refers to cases where single acts have occurred, viz., the nonresident motorist decisions, where jurisdiction is based upon a single act done by a nonresident within

see why a statement by the majority of what they regarded as the proper rule could be considered to be "an unnecessary discussion". The discussion by the Chief Justice, writing for the majority of the Court, it is believed, was most appropriate. No fault should be found with the opinion for the reason that it was obiter dicturn. It is to be regretted that Justice Black, since he decided to write a separate concurring opinion, did not go further and state his views more specifically.

8 The opinion does not elaborate upon the factors of converience and inconvenience to the parties in the instant case. Perhaps it was thought that weigling them was unnecessary since the question was primarily a legal one.

${ }^{9}$ St. Clair v. Cox (1882) 106 U.S. 350; Connecticut Mutual Life Ins. Co. v. Spratley (1889) 172 U.S. 602 ; Pennsylvania Lumbermen's Mut. Fire Ins. Co. v. Meyer (1905) 197 U.S. 407 ; Commercial Mutual Accident Co. v. Davis (1909) 213 U.S. 245; International Harvester Co. v. Kentucky, supra note 3 ; cf. St. Louis S. W. Ry. Co. v. Alexander (1913) 227 U.S. 218, Ann. Cas. 1915B, 77.

10 St. Clair v. Cox, supra note 9, at 360; Old Wayne Mut. Life Ass'n v. McDonough (1907) 204 U.S. 8, 21; Frene v. Louisville Cement Co. (App. D. C. 1943) 134 F. (2d) 511, 146 A.L. R. 926, and cases cited.

11 Missouri, K. \& T. Ry. Co. v. Reynolds (1921) 255 U.S. 565 ; Tauza v. Susquehanna Coal Co. (1917) 220 N. Y. 259; 115 N. E. 915 ; cf. St. Louis S. W. Ry. Co. v. Alexander, supra note 9; Frene v. Louisville Cement Co., supra note 10. See also Whitaker v. MacFadden Publications, Inc. (App. D. C. 1939) 105 F. (2d) 44, (1940) 28 CALIF. L. REv. $22 \%$. 
the forum which gives rise to a cause of action. ${ }^{12}$ From these decisions he draws the conclusion that dividing lines are not drawn on a purely quantitative or mechanical basis. He states that the nature and quality of the acts done furnishes the test to be applied to solve the jurisdictional problem. Reference is made to the fact that a corporation doing acts in a foreign state enjoys the benefits of the protection of the laws of that state; that an obligation may arise out of such acts and that procedure requiring the corporation to respond to actions arising out of an act or acts done can "hardly be said to be undue." The conclusion was then reached, by application of the standards stated, that a court of the state of Washington had jurisdiction of the action against the Delaware corporation to render a personal judgment to enforce liability to contribute to Washington's state unemployment fund, where the amount to be paid was based upon a percentage of the commissions paid the salesmen working for the corporation in the state of Washington. Traditional conceptions of "fair play and substantial justice" it was said, support the jurisdiction of the Washington courts, hence it could not be said that the due process clause was violated. Thus the "presence" theory is discarded; the "fair play and substantial justice" theory is put in its place.

It may be difficult if not impossible to reconcile the holding in this case with previous decisions of the Supreme Court of the United States. Previous decisions have indicated that solicitation of business by agents of a foreign corporation is not enough to furnish a basis for jurisdiction over it to render a personal judgment against it. ${ }^{13}$ Perhaps it may be said that the instant was not a case of mere solicitation since the foreign corporation also from time to time had rented rooms in the state of Washington in which samples of its merchan-

12 Kane v. New Jersey (1916) 242 U.S. 160; Hess v. Pawloski (1927) 274 U. S. 352.

13 People's Tobacco Co. v. American Tobacco Co., supra note 4; Minnesota Commercial Men's Ass'n v. Penn. (1023) 261 U. S. 140. But see American Asphalt Roof Corp. v. Shankland (1928) 205 Iowa 86́2, 219 N. W. 28, 60 A. L. R. 986, and Notes, ibid. 994 ; L. R.A. 1916E, 236; (1927) 14 VA. L. Rev. 133; Thurman v. Chicago M. St. P. R. Co. (1926) 254 Mass. 569, 151 N. E. 63, 46 A. L. R. 563 ; Gloeser v. Dollar S. S. Lines, Inc. (1934) 192 Minn. 376, 256 N. W. 666, 95 A. L. R. 1470, Note (1935) 19 MnN. L. REv. 565 ; International Shoe Co. v. Lovejoy (1934) 219 Iowa 204, 257 N. W. 576, 101 A.L.R. 122, and Note, ibid. 126; Barnett v. Texas \& P. Ry. Co. (1944) 145 F. (2d) 800, Swan, $\mathrm{J}$. dissenting.

Justice Rutledge, writing the opinion in Nippert v. City of Richmond (Feb. 25, 1946) ........ U.S. ........, 66 S. Ct. 586, decided since this article was written, said that International Shoe Co. v. State of Washington, supra note 1 , decided that regular and continuous solicitation constitutes "'doing business,' contrary to formerly prevailing notions." Ibid. at 589. 
dise were displayed. Whether a distinction based upon the additional factor of renting sample rooms can or should be drawn seems not very helpful if the quest was, as it seems to have been, for a better rule for future cases. Nor does there seem to be much comfort in the idea that the "nature and quality" of the acts done rather than the "quantity" of the acts done furnishes the true criterion. That the "presence" theory is vague and unsatisfactory will be conceded but is not the "fair play and substantial justice" theory also somewhat vague and unsatisfactory? Neither rule will afiord definite information to corporations contemplating some activities in other states. They must, in the future as in the past, act at their peril. In the future as in the past the facts in each case must be examined by the court as the case arises; and each case presents a constitutional law problem. ${ }^{14} \mathrm{It}$ is believed that this is not a desirable state of the law in the United States where business transactions are not fenced in by state lines, but on the contrary continuously cross state lines. It is suggested that a proper and simpler solution of this important problem ${ }^{15}$ is to hold that an appropriate court of a state has jurisdiction of an action against a foreign corporation which arises out of acts done by its agent or agents which create liability or constitute a part of a series of acts which culminate in creating liability provided due notice of the action is given. The suggested rule, if sound, cannot be condemned as a radical departure from accepted doctrine when it is borne in mind that originally the opinion prevailed that a corporation could only be sued in the state that created it. ${ }^{10}$ This unsound

14 The Supreme Court of the United States applying the "presence" theory has said that "each case must depend upon its own facts." International Harvester Co. of America v. Kentucky, supra note 3. Inasmuch as a federal constitutional question is involved in all of these cases it seems desirable to find a principle which will not depend upon minor differences of fact. Fewer facts regarded as operative facts will produce less vagueness and less litigation.

15 See 20 C. J.S. $45-62$, citing scores of recent cases dealing with the question "What Constitutes Doing Business". See also the opinions of the judges of the Washington supreme court in the instant case for the decisions in a single jurisdiction.

16 Henderson, Foreign Corporations in American Constitutional Law (1918) 77. See Cahill, Jurisdiction over Foreign Corporations (1917) 30 HARv. L. REv. 676, 686; Scott, Fundameantals of Procedure in Actions at Law (1922) 52 ; see also Bank of Augusta v. Earle (1839) 38 U.S. (13 Pet.) 519, 588. There Chief Justice Taney said: "It is very true, that a corporation can have no legal existence out of the boundaries of the sovereignty by which it is created. It exists only in contemplation of law, and by force of the law; aud where that law ceases to operate, and is no longer obligatory, the corporation can have no existence. It must dwell in the place of its creation, and cannot migrate to another sovereignty." 
theory later was supplanted by the "implied consent"17 theory which in turn was supplanted by the "presence" theory..$^{18}$ The proposed rule seems fair both to the plaintiff who is often a citizen of the state and to the foreign corporation. As was pointed out by the learned Chief Justice a corporation that conducts activities in a foreign state enjoys the protection and benefits of its laws and hence should be required to respond to an action against it arising out of activities carried on there. In this case the salesmen were domiciled in Washington over a period of three years. The Shoe Company had the benefit of protection given to them by that state. It was therefore quite reasonable to hold that the principal should respond to an action arising out of their employment and activities in the state that gave them and the Shoe Company the protection of the laws of the state. A corporation can only act through natural persons. Protection for these persons is in reality protection for the corporation.

The true basis for the suggested rule is the power of the state. The only limitations upon the jurisdiction of the courts of an American state are to be found in the constitution of the state, the Constitution of the United States and the same extensive powers possessed by the other states of the United States. ${ }^{19}$ No limitation is known in any of these sources which prevents appropriate courts of a state from exercising jurisdiction over actions arising out of acts done within the state which create legal liability provided that by service of process jurisdiction is acquired over the particular defendant against whom the liability is sought to be enforced. The state has the power, it is believed, to subject both nonresident natural persons and foreign corporations to the jurisdiction of its courts if either has done an act in the state which has created legal liability. It cannot be said that there is arbitrary exercise of the power of a state where the nonresident has had the protection of its laws while in the state. A foreign corporation may be kept out of the state ${ }^{20}$ and it may also be excluded

17 Insurance Co. v. French (1855) 59 U.S. (18 How.) 404; Henderson, loc. cit. supra note 16; Scorr, op. cit. supra note 16, at 54; Cahill, op. cit. supra note 16, at 689-696.

18 Barrow Steamship Co. v. Kane (1897) 170 U.S. 100.

19 U.S. Const., Amend. X. Texas v. White (1868) 74 U.S. (7 Wall.) 700; Lane County v. Oregon, ibid. at 71; Tennessee Coal Iron \& R. R. Co. v. George (1914) 233 U.S. 354; Nebbia v. New York (1933) 291 U.S. 502. Burdick, The AMrerican ConstiTUTION (1922) 435; ROTTSCHAEFFER, CONSTTTUTTONAL LAW (1939) $\$ \$ 97-99$ and 338; Winson, Constitutional Governaent (1921) 183, 184.

20 Paul v. Virginia (1868) 75 U.S. (8 Wall.) 168; Scott, Jurisdiction over Nonresi- 
if it does not consent to the jurisdiction of its courts and service of process as to causes of action arising out of acts done in the state. ${ }^{21}$ These propositions being settled law it follows that a state has the power to subject foreign corporations to the jurisdiction of its courts as to actions of this character. ${ }^{22}$ Ample support for this view is to be found in cognate decisions of the Supreme Court of the United States. In point are decisions of that Court upholding the validity of statutes subjecting nonresident motorists to the jurisdiction of the courts of the state where a negligent act occurred ${ }^{23}$ and the decision of the Supreme Court of the United States upholding the validity of a state statute conferring jurisdiction upon the courts of that state over actions arising out of the sale of securities by a nonresident, through his agents. ${ }^{24}$ If state statutes are valid, i.e., satisfy the due process clause, and pass other constitutional barriers; and confer jurisdiction upon the courts over actions arising out of wrongful acts of non-

dent Doing Busiress Within a State (1919) 32 HARv. L. REv. 871; Henderson, op. cit. supra note 16, at 101.

21 Barrow Steamship Co. v. Kane, supra note 18; Pennsylvania Fire Ins. Co. v. Gold Issue Mining Co. (1917) 243 U. S. 93; Bond, Goodwin \& Tucker v. Superior Court (1933) 289 U.S. 361, 89 A. L. R. 653. See also Cahill, loc. cit. supra note 16.

${ }^{22}$ Scott, loc. cit. supra note 20; McBaine, Service Upon a Nonresident by Service upon His Agent (1934) 23 CALIF. L. REv. 482.

23 Hess v. Pawloski, supra note 12. In these cases statutes providing for service of process outside of the state where the action is commenced have been held valid. See Scott, Jurisdiction over Nortresident Motorists (1926) 39 HARv. L. REv. 563; Hinton, Substituted Service on Nont-Residerts (1925) 20 Irr. L. Rev. 1 ; Culp, Process in Actions against Non-Resident Motorists (1934) 32 MiCH. L. REv. 325; (1928) 16 CALIF. L. REv. 428.

The explanation, often made in these cases, that jurisdiction exists because of "implied consent" or the "police power", is not convincing. The "implied consent" is fiction pure and simple, a myth, and the term "police power" means nothing more than the power of a state to legislate for the general welfare of its people. Nebbia v. New York, supra note 19. RotTsCEAEFFER, op. cit. supra note 19, $\S 223,224$ (discussing "police power").

24 Henry L. Doherty \& Co. v. Goodman (1935) 294 U.S. 623. The validity of an Iowa statute was upheld which authorized service of process upon a nonresident individual who, through agents, sold securities in that state. The action arose out of a sale made by an agent. The agent was served with process. The statute restricted jurisdiction and service of process to "actions growing out of or connected with the business of that office or agency." For a detailed discussion of the case see McBaine, loc. cil. supra note 22.

Compare also a Maryland statute providing that foreign corporations shall be subject to the jurisdiction of the Maryland courts "on any cause of action arising out of a contract made within this state or liability incurred for acts done within this state." [MD. CoDE (Flack, 1939) Art. 23, § 119(d)]. See Reiblich, Jurisdiction of Marylard Courts over Foreign Corporations under the Act of 1937 (1938) 3 MD. L. REv. 35; 
resident natural persons committed within the state, no sound reason exists why a similar result may not be reached by judicial decisions respecting foreign corporations. In both situations the questions

Reiblich, Revision of the Maryland Foreign Corporation Law (1938) 38 CoL. L. REv. 1060.

Also compare a Pennsylvania statute providing that any nonresident owner, user or tenant of real property in that state shall by such ownership, etc. constitute the Secretary of the Commonwealth his agent for the service of process in actions commenced in Pennsylvania courts against the owner, etc. "arising out of or by reason of any accident or injury occurring within the commonwealth in which such real estate, footways and curbs are involved." [Act of July 2, 1937, P.L. 2747, 12 PA. STAT. (Purdon, Supp. 1937) § 331]. See Note (1938) 87 U. of PA. L. Rev. 119 discussing Dubin v. City of Phila. and Lesher (1938) $34 \mathrm{~Pa}$. D. \& C. 61, upholding the validity of the statute. See Stoner v. Higginson (1934) $316 \mathrm{~Pa}$. St. 481, 175 Atl. 527, (1935) 83 U. OF PA. L. REv. 683, upholding the validity of a statute providing for service of process apon an agent of a nonresident individual doing business in the commonwealth. Jurisdiction was upheld in a tort action arising out of business done there.

Compare also a New York statute providing for jurisdiction and service of process upon a nonresident natural person engaged in business in New York, in any action arising out of such business by service upon the person in charge of the business and also notice of the service, accompanied by a copy of the complaint and the summons, sent to the defendant by registered mail. It also provides for service of the process upon the person in charge and personal service outside the state in lieu of registered mail. [N. Y. Civ. Prac. Act. \& 229-b, effective April 15, 1941, Thompson's Laws of N. Y. (1942 Supp.) 1413.] The statute is discussed in (1940) 40 Cor. L. Rev. 1105 ; (1940) 53 HaRv. L. REv. 1061. This statute was originally passed in 1940. It was amended in 1941.

See Teckes-Zicheubaum Inc. v. McCarthy (1943) 290 N. Y. 437, 49 N. E. (2d) 517 discussing section 229-b of the New York Civil Practice Act and holding it not applicable under the facts to an action against trustees of a bankrupt foreign corporation. The reasoning it seems leads to the conclusion that a foreign corporation as well as a natural person, may be subject to the jurisdiction of the courts of a state in actions arising out of acts done within the state. No sound argunent can be made which will result in the conclusion that the state has more power over a nonresident individual who does an act within the state than it has over a foreign corporation, when the action in question arises out of the act done. Only by use of the spurious doctrine of "consent" or the fictitious doctrine of "presence" can a result be reached which places foreign corporations in more favorable positions than nonresident individuals under the Constitution of the United States. Agents of a foreign corporation like agents of a natural person receive the protection of the laws of the state when they act for a principal. In each case, looking at the question realistically and from the standpoint of the power of the state, this is sufficient basis for jurisdiction in actions arising out of business done in the state which affords protection. See also Interchemical Corporation v. Mirabelli, 54 N.X.S. (2d) 522 .

See Daum, Jurisdiction Over Non-Residents (1934) 19 Iowa L. REv. 421, suggesting that no valid distinction can be made between nonresident individuals and foreign corporations for jurisdictional purposes, that both should be amenable to the jurisdiction of the courts to enforce liability arising out of acts done within the forum.

See also Deutsch v. Hoge (C. C. A. 2d, 1944) 146 F. (2d) 201 where service was made in New York under section 229-b of the New York Civil Practice Act upon a soliciting agent of an Ohio partnership. The court held that the partnership was not 
raised are the same, viz., the power of the state and the fairness of the notice. This rule will be fair to the corporation which elects to transact business beyond the boundaries of the state that creates it. It is not thought that this rule, simple as it is, will never be the subject of disagreement as to its application even by well-informed lawyers and judges. Questions may arise as to whether the alleged liability did arise out of the acts of the corporation in the foreign state or whether the act or acts in the state did constitute a part of a series of acts which resulted in creating legal liability, but solution of border line cases, it is believed, will be easier and more satisfactory than solution by application of the "presence" theory or the "fair play and substantial justice" theory.

The result in the instant case is sound. The liability enforced arose out of acts done by the Shoe Company in the state of Washington. Perhaps the result can be sustained on all of the three theories mentioned. Had, however, the suggested rule as to jurisdiction been in force no well-informed lawyer or judge would have had a doubt that an appropriate court of Washington had jurisdiction, if there had been proper service of process. An action by a state against a foreign corporation to enforce a liability to contribute to its unemployment fund, where liability to contribute is based upon the salaries or commissions paid its agents engaged in the business of soliciting orders in the state for merchandise to be shipped into the state, would not have produced any difficulty for either the bench or the bar. Nor would an action for damages for deceit or for breach of warranty of the merchandise sold present a difficult problem of jurisdiction.

Assuming that a court of any state has jurisdiction to render a personal judgment against a foreign corporation, which it is believed it has when the action arises out of an act done in the forum state, the further question arises as to the service of process that must be made to subject the particular defendant to its jurisdiction. To put the

doing business in New York. L. Hand, J dissented. He concluded that the action arose out of business done in New York, that acceptance outside the state of an offer made in the state and the soliciting of business there was engaging in business. He remarked: "We have a state statute to construe ( $\$ 229-\mathrm{b}$ of the New York Civil Practice Act); a statute narrower in scope than the full power of the state. I say this because it is now settled that a state may subject a non-resident to the jurisdiction of its courts without personal service, if the action be based upon an act of the non-resident while personally within the state." [Citing Kane v. New Jersey; Hess v. Pawloski, both supra note 12; and Henry L. Doherty \& Co. v. Goodman, supra]. 
matter another way, there are two questions involved when a court is asked to award a personal judgment against a foreign corporation: (1) whether the court has power over the class of cases in which the particular suit falls and (2) whether the defendant, in a lawful manner, has been commanded to appear. A proper court of state $A$ has jurisdiction, in a transitory action, to render a personal judgment against $D$, a citizen of state $B$, who is temporarily within the boundaries of state $A{ }^{25}$ However, no personal judgment can be awarded against $D$, a nonresident, or $C$, a resident, without service of lawful process. ${ }^{20}$ In the instant case there was no serious question as to the validity of the service of process which was made. The serious question was whether the Washington court had jurisdiction over this type of case. The service followed the Washington statute. A notice of assessment of the tax claimed was personally served in Washington upon one Alley, one of defendant's salesmen. A copy of the notice was also sent by registered mail addressed to the company in St. Louis, Missouri. ${ }^{27}$ Actions against foreign corporations for personal judgments perhaps are not likely to fail because service of process cannot be made since usually there is some agent in the state upon

25 Barrell v. Benjamin (1819) 15 Mass. 354; Darrah v. Watson (1872) 36 Iowa 116; Foss v. Richards (1927) $126 \mathrm{Me} .419,139$ Atl. 313. Restatement, Conflict of Laws § 78. Beale, Jurisdiction of Courts Over Foreigners (1913) 26 HARv. L. REv. 283, 285. For additional cases see 15 C. J. 786; 21 C.J.S. 113.

26 Pennoyer v. Neff (1877) 95 U.S. 714 (service by publication upon a nonresident) ; McDonald v. Mabee (1917) 243 U. S. 90, L. R. A. 1917F 458 (service by publication upon a resident temporarily outside the state held invalid); Bardwell v. Collins (1890) 44 Minn. 97, 46 N. W. 315, 9 L. R. A. 152, 20 Am. St. Rep. 547. Compare Goldey v. Morning News (1894) 156 U.S. 518, where the service was upon an agent of the foreign corporation, the president, but the corporation had done no business in the state; and Flexnor v. Farson (1918) 248 U.S. 289, where the holding was that service of process upon a former agent of a nonresident individual did not give the court jurisdiction over the person; Roller v. Holly (1900) 176 U.S. 398, where the notice given did not afford sufficient time to answer.

27 The dissenting judges said that the defendant was not properly served with process. The reason given was that the Shoe Company was then doing only interstate business; that corporations doing only interstate business are not subject to Washington laws. This argument merely means that the Washington court has no jurisdiction over the action regardless of the kind of service of process that was made. If the problem is viewed as presenting the distinct questions, viz., jurisdiction over the class of actions to which the case under consideration belongs and jurisdiction over the person of the defendant correct analysis of the problem is much more likely to be made. See St. Louis S. W. Ry. Co. v. Alexander (1912) 227 U.S. 218; Mechanical Apphance Co. v. Castleman (1910) 215 U.S. 437; West Cove Grain Co.v. Bartley (1909) 105 Me. 293, 74 Atl. 730; Kalde v. Kalde (1928) 207 Iowa 121, 222 N. W. 350; White v. Neptune City (1893) 56 N. J.L. (27 Vroom) 222, 28 Atl. 378; Shelton ${ }^{\circ}$ v. Snyder (1920) 126 Va. 625, 102 S.E. 83 ; Cooper v. Davis (1931) 248 N. Y. Supp. 227. In St. Louis S. W. Ry. Co. v. Alexander, 
whom personal service may be made pursuant to state statutes. ${ }^{28}$ It may of course happen that there is no agent in the state upon whom service may be made. In this situation no personal judgment could be obtained under existing state statutes. To prevent this undesirable state of affairs it is suggested that state legislation may be enacted providing for service of process upon a state official upon whom is imposed a duty to mail the summons, or for personal service of process outside the state. Authority for the validity of this type of service of process may be found in the numerous decisions of the state courts and of the Supreme Court of the United States upholding this method of service in actions against nonresident motorists and other nonresident individuals. In the leading case of Hess $v$. Pawloskita the Supreme Court of the United States upheld a Massachusetts statute which provides that service may be made upon a state official and imposes a duty to notify the nonresident defendant by registered mail. These statutes now also commonly provide that the nonresident may be personally served outside the state. Since this type of service has been upheld ${ }^{30}$ in actions against a nonresident

supra note 9, Mr. Justice Day said: "In this class of cases, where it is undertaken to hold a corporation personally liable in a foreign jurisdiction, two questions ordinarily arise: the first, Was the corporation within the jurisdiction in which it is sued?; the second, Was process duly served upon an authorized agent of the corporation?"

In West Cove Grain Co. v. Bartley, supro, the court said: "There are three essentials to legal jurisdiction: First, the court must have cognizance of the class of cases to which the one to be heard belongs, or, in other words, jurisdiction of the subject-matter; second, the proper parties must be present, or power be had to compel their attendance, or, in other words jurisdiction of the parties; tbird, there must be authority to decide in substance and effect."

In Kalde v. Kalde, supra, the Iowa court states the problem as follows: "Jurisdiction includes both the subject-matter and the person of the defendant. Witlout question, the court had jurisdiction of the subject-matter. Did it bave jurisdiction of the person of the defendant? This is the sole question which is properly presented to us on this appeal."

28 West Pub. Co. v. Superior Court (1942) 20 Cal. (2d) 720, 128 P. (2d) 777, cert. den., (1942) 317 U.S. 700 (1943) 31 CALIF. L. REv. 337.

29 Supra note 12.

30 Silver Swan Liquor Corp. v. Adams (1941) 43 Cal. App. (2d) 851, 110 P. (2d) 1097; Cax. Verr. Code $\S 404$. See Culp, Recent Developments in Actions Against Norresident Motorists (1938) 37 Micr. L. REv. 58 and Culp, loc. cil. supra note 23.

See also Milliken v. Meyer (1940) 312 U.S. 712, upholding personal service outside the state where the court had jurisdiction over the action; and Blackmer v. United State (1932) 284 U.S. 421, upholding service of a summons in France by an American consul. See Dodd, Jurisdiction in Personal Actions (1929) 23 IxL. L. Rev. 427.

The New York statute (Crv. Prac. Acr § 229-b) supra note 24, provides an elaborate scheme for service outside the state. It 2uthorizes such service by a resident or citizen of New York; a sheriff, under-sheriff, deputy sheriff or constable of the county in which 
motorist no reason is seen why it may not be sufficient notice to a foreign corporation, which has committed acts within a state out of which liability has arisen and for the enforcement of which an action has been commenced against it. Foreign corporations which do acts by agents in a state, out of which liability arises, are in no better position than nonresident individuals.

Apparently the new rule of "fair play and substantial justice" applies to actions arising out of acts done within the state and to actions arising out of acts done outside of the state. It does not apply to actions where the foreign corporation has been granted a license and has consented to service of process. A much more difficult problem, however, is presented where jurisdiction is asserted by a court of a state over a foreign corporation in an action arising elsewhere, where the foreign corporation has acted through agents in the state without its permission and has not consented to jurisdiction and service of process. This problem is not now discussed. Obviously it cannot be solved by the suggested rule since the cause of action does not arise out of an act done within the state. Perhaps in this class of cases there may be greater merit in the "fair play and substantial justice" theory than in the "presence" theory. In these cases factors of convenience and inconvenience seem pertinent as well as the question of imposing undue burdens upon interstate commerce. Any way one looks at the problem it is another and different one which deserves careful re-examination.

the service is made; an officer authorized by New York law to take acknowledgment of deeds; an attorney, solicitor, advocate, or barrister qualified to practice law in the jurisdiction where the service is made; or a United States marshal, or deputy marshal. 